\title{
How We Design Our Study Space during Pandemic Covid-19?
}

\author{
Bangun I R Harsritanto ${ }^{* 1}$, Satrio Nugroho ${ }^{1}$, Wulani Enggar Sari ${ }^{2}$, Rona Fika Jamila ${ }^{3}$, \\ Gentina Pratama Putra ${ }^{3}$ \\ ${ }^{1}$ Architecture Department, Engineering Faculty, Universitas Diponegoro, Semarang, Indonesia \\ ${ }^{2}$ Architecture Department, Parahyangan Catholic University, Bandung, Indonesia \\ ${ }^{3}$ Architecture Department, Engineering Faculty, Universitas Mercu Buana, Jakarta, Indonesia
}

\begin{abstract}
The pandemic covid 19 in Indonesia has entered the second year and may be extended into the next several periods of time. As academia, study space has shifted from physical office and class into virtual space. Several design adaptations have been applied in our home to accommodate the preference of users as students/lecturers in teach, work, and study. This study was performed by literature review, questionnaires and software simulation. The result showed that there is a strong relation between virtual space and physical space during a pandemic; the preference of study space design shows a generic template for further developments.
\end{abstract}

\section{Introduction}

The COVID--19 was informed on China at the end of 2019 and made the big world problem until present [1-3] as part of United Nations, The World Health Organization (WHO) started to announce about nCOVID-1919 as a pandemic in March 2020 as the fast-spreading of COVID-19 situation at many countries [4,5]. Until 29 May 2021, COVID--19 has spread through 222 countries with 170,256,454 cases of positive infected patients, 152,148,821 cases of recovered and 3,540,426 cases of death [6].

Many countries have announced a lockdown policy and night curfew to stop the spreading [7] as a lesson learnt from the previous strategy of a pandemic on earth such as plague, Spain flu, etc. The pandemic has affected every aspect, such as economics [8], educations [9], tourism [10], and also religious aspect [11].

Indonesia first case of COVID-1919 was found at Depok city In Indonesia with two suspects on 2 March 2020 [12,13]. Since that day, the pandemic started to infect people that not aware of the physical and social distancing [14]. The total covid-19 cases in Indonesia reached 1.74 million cases with detail of 1.61 million were cured, and 48,305 were passed away. In 2021, the month of January has reached 14,518 new cases, which is the highest case in Indonesia [15]

* Corresponding author: bangunirh@arsitektur.undip.ac.id 
The big impact for workers and students, the world started to more encourage in Work from Home (WFH) and Learn from Home (Pembelajaran Jarak Jauh=PJJ). Both home schemes were part of telecommuting concept. Telecommuting or telework was a condition when workers were being given chances to finish or continue their duty at Home rather than directly in the office $[16,17]$. Telework is a form of flexible work with a flexible place [18] on flexible time $[19,20]$. Furthermore, the lockdown and night curfew brought Home as the Office or School, and $80 \%$ of them must spend the most day on it [21]. Therefore, People shall make an adjustment on their Home for office or school or cope with the existing condition of Home. With desirable function and compatible use of certain space in Home, people will be satisfied and more productive [22].

This study will investigate people adaptation to their Homes to accommodate the learn from home activities. Some literature, questionnaires and software simulations were carried out to present the investigations.

\section{Method}

This study uses a literature study and online questionnaires. The data is obtained from an online survey being analysed with literature and, later on, will be simulated with design software to make the illustration of desirable space for studying from home.

\section{Material and Discussion}

\subsection{The physical demand}

\section{apakah sebelum KLB COVID19 ini telah melakukan kerja/belajar online?} 130 jawaban

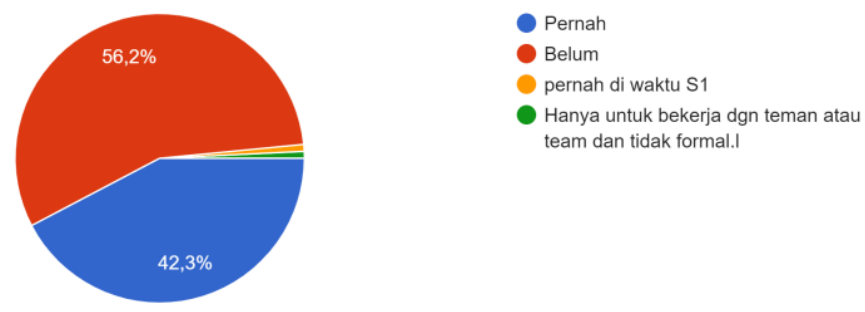

Fig. 1. Preparation of Learn from Home before Pandemic.

Most of the respondents (56\%) were never done any work/study from home with online connectivity (figure 1). There was no chance for them to study from home online because there is some regulation in Indonesia $[23,24]$ and negative sentiments about studying not in physical class or not attending a direct teaching course [25]. These conditions made a new normal habit that being promoted by the government, health institutions, higher education departments have meet contra-productive clause. As official institutions that have legitimation to make regulation have to decline their own publications in the past and need to massively promote the health protocols and developed concept of education to protect their citizens in every place in Indonesia. The condition of the archipelago that has not to have similar internet connectivity also made the WFH and LFH have to face rooted habits of people. 
tempat kerja/belajar online

130 jawaban

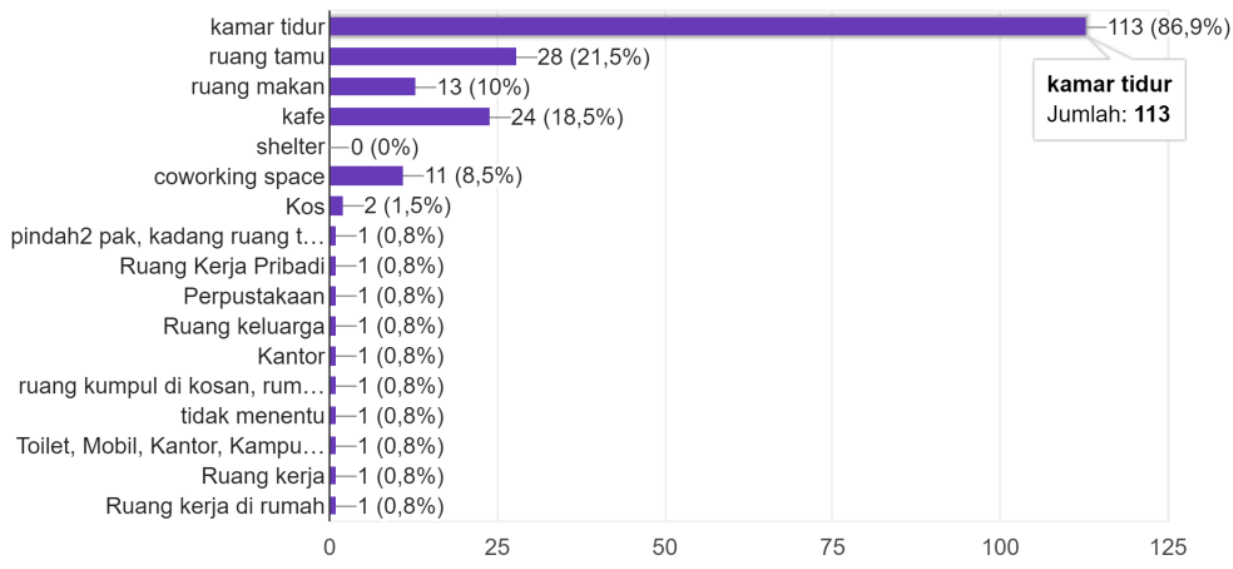

Fig. 2. Place preferences to do telework/study.

From figure 2, Most of the student prefers to make their bedroom as the study room $(86.9 \%)$. At the same time, living room and café outside from home had only $20 \%$ of the respondents that made them into second and third place preferences. Conducted speed dating sessions to investigate how bedroom forms and behaviours influence perceptions of value, revealed how new technologies might better support self-exploration and reflection, as well as how they could complicate identity construction processes [26]. Teens as students feel more comfortable doing many things in their bedroom rather than in another place. The private placement of the bedroom just seems like their own territory so that no other person can disturb them during work/study with their gadgets. The solitude state of learning/working with gadgets is also reflected in figure 3. 69.2\% of people prefer to work/learn alone in their work learn places. In other facts, the internet may connect them with other colleagues in the virtual spaces.

kondisi favorit di ruangan untuk bekerja atau belajar online

130 jawaban

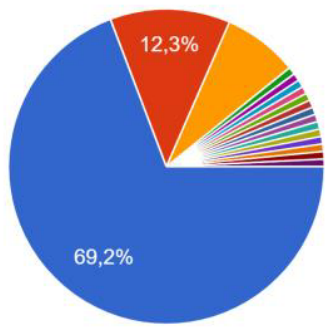

sendirian

bersama kelompok

ramai juga tidak masalah

Sendirian atau berkelompok tidak ma...

Kondisional

suara tidak menyebar keluar ruangan

Dengan ditemani musik kesayangan

Saya ambivert pak, tergantung suasa...

Fig. 3. Preferences on companion during WFH. 
kondisi udara favorit di ruangan untuk bekerja atau belajar online

130 jawaban

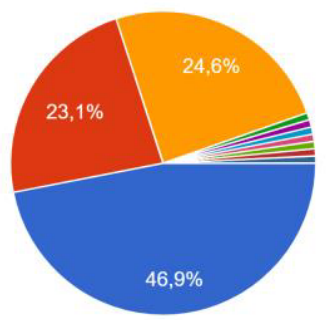

menyalakan AC

cukup udara biasa

minimal ada kipas angin

Yang penting tidak kepanasan

udara biasa cuku sebenernya tapi kal...

Tergantung kondisi udara, kalau pana...

Ac atau udara biass

AC boleh, udara natural boleh

Fig. 4. Preferences of air condition of work/study place.

In the more deep study, people like to turn on their Air Conditioner (AC) during activities at home, as shown in figure 4 . They prefer to make their place more breeze and cool with $\mathrm{AC}$ or ceiling/desk fan. Cool scent has brought many motivations in working or learning rather than natural ventilation. With a cool atmosphere, people were attracted and more comfort in doing their duties and gained more experience [27].

\section{lokasi laptop/gawai favorit di ruangan untuk bekerja atau belajar online}

130 jawaban
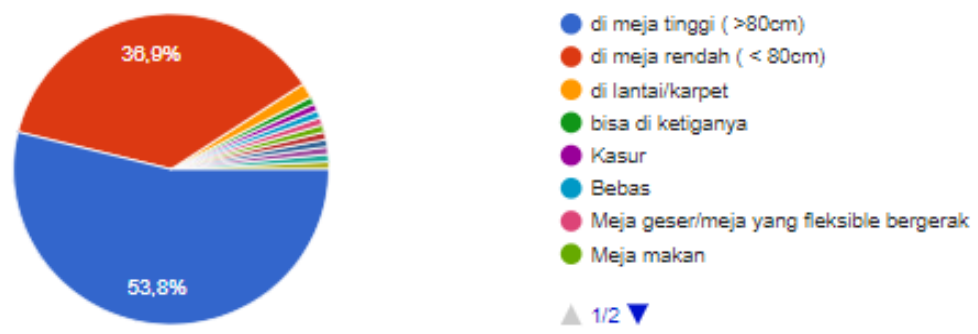

Fig. 5. Preferences of gadget position.

The last point of people preference in making their work/study place during a pandemic is gadget positions. We all know that gadgets like laptops, smartphones, tablets and other electronic devices are mandatory things in online activities. Most respondents choose to put their gadgets on the desk/table (figure 5). They avoided working on the floor or other furniture. This preference might relate to ergonomics and their need to see the monitor on the same level of the head. That situation could be reached only if they put the gadgets above the table.

From the survey results, we can assume that at the beginning of a new era of working/learning from home, people would like to add another function of their bedroom to be their workstation or class. Some modifications, such as Air conditioner and fans for making cool atmosphere; cleaning the bedroom table for put their gadgets were done to meet their demand of comfort work/study space. Their basic of that activity shown that people become more solitaire rather than communal, and ego-freak rather than natural friendly that love to spend activities in more public space with keeping the health protocols. 


\title{
3.2 The Disturbance
}

\author{
hal yang dihindari ada di ruangan saat kerja/kuliah online \\ 130 jawaban \\ Kebisingan \\ Tidak ada \\ Wifi lemot \\ Kebisingan \\ kegaduhan \\ Makanan \\ panas,banyak nyamuk $(-)$ \\ Teman yg berisik, mati lampu, paket habis
}

Fig. 6. The disturbance.

After the preferences were shown before, some disturbances were collected in figure 6 . The main problems for doing Work/Learn from Home is noise or audio disturbance. There is a correlation between the vocal intensity of the teachers and the noise in the classroom. The vocal intensity measures also relate to the symptoms of vocal tract discomfort before and after classes [28]. People need to be concentrated or focused during their tasks. Some noise may distract them and make the place not comfortable anymore. Therefore, the place must be far from audio disturbances. There are also other problems, such as internet connections, food, and electricity problems that make problems on their work/study from home.

\subsection{The simulation}

There were: 1. Solicitation, 2. Air-conditioned, 3. Gadget on the table, 4. Far from noise demand of preferable work station and home's class related to our survey result. The illustration of that condition may represent in figure 7 . In the middle of the COVID-19 pandemic, many companies/schools are implementing voluntary or mandatory work/learn-from-home policies. That means a lot of us are dealing with an unusual challenge: working/learning from home, full-time. Granted, some may be used to this, but most of the population may feel lost in the exercise. A plan of work-from-home as well practices are doing rounds on the internet, but it takes a lot of words to match up to a well-done illustration - like this Working from Home illustration (figure 7). 


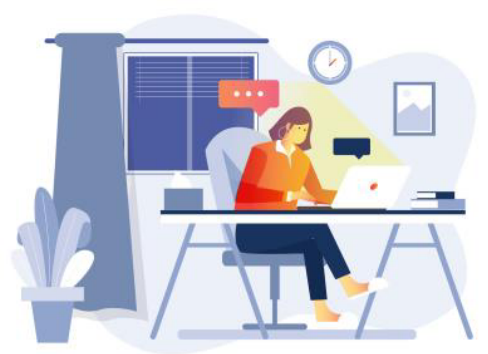

Fig. 7. The illustration of WFH preferences [29].

\section{Conclusion}

The adaptation of work/learn from the home condition during the COVID-19 pandemic is mandatory. People demanded a very comfortable place similar to their office or class outside of their home. Some adaptive designs of their home part were done to meet their needs. Most people would like to use their bedroom with table and air conditioner on to fulfil their demand of work/class at home. In their bedroom, they also can control and avoid the audio disturbance because the virtual space on their gadget needs to be more listened to rather than the home sounds.

This research was financially supported by The Faculty of Engineering, Diponegoro University, Indonesia, through Strategic Research Grant 2021.

\section{References}

[1] M. K. Daga, N. Kumar, J. Aarthi, G. Mawari, S. Garg, I. Rohatgi, From SARS-CoV to Coronavirus Disease 2019 (COVID-19)-A brief review, Journal of Advanced Research in Medicine (2019)

[2] N. Woznitza, S. S. Hare, A. Nair, Covid-19 pandemic: Summary of current and emerging issues for radiographers, Work, 20, (2019).

[3] Y. R. Guo, Q. D. Cao, Z. S. Hong, Y. Y. Tan, S. D. Chen, H. J. Jin, K. S. Tan, D. Y. Wang, Y. Yan, The Origin, Transmission and Clinical Therapies on Coronavirus Disease 2019 (COVID-19) Outbreak - An Update on the Status, Military Medical Research, 7(11), (2020)

[4] D. Cucinotta, M. Vanelli, WHO declares COVID-19 a pandemic, Acta Bio-Medica: Atenei Parmensis, 91(1), 157-160 (2020).

[5] A. Spinelli, G. Pellino, COVID-19 pandemic: perspectives on an unfolding crisis, The British Journal of Surgery (2020)

[6] Worldometer, Covid-19 coronavirus pandemic, Retrieved from https://www.worldometers.info/coronavirus/

[7] A. Wilder-Smith, D. O. Freedman, Isolation, quarantine, social distancing and community containment: pivotal role for old-style public health measures in the novel coronavirus (2019-nCoV) outbreak, Journal of Travel Medicine, 27(2), (2020)

[8] N. Fernandes, Economic effects of coronavirus outbreak (COVID-19) on the world 
economy, (2020)

[9] A. Abidah, H. N. Hidaayatullaah, R. M. Simamora, D. Fehabutar, L. Mutakinati, The impact of Covid-19 to Indonesian education and its relation to the philosophy of "Merdeka Belajar", SiPoSE: Studies in Philosophy of Science and Education, 1(1), 38-49 (2020)

[10] S. Gössling, D. Scott, C. M. Hall, Pandemics, tourism and global change: a rapid assessment of COVID19, Journal of Sustainable Tourism, 1-20 (2020)

[11] Harsritanto, I. R. Bangun, S. Nugroho, F. Dewanta, Undesignated Academic Mosque Response Toward COVID--19 Pandemic, E3S Web of Conferences 202, (2020)

[12] R. Djalante, J. Lassa, D. Setiamarga, A. Sudjatma, M. Indrawan, B. Haryanto, C. Mahfud, M. S. Sinapoy, S. Djalante, I. Rafliana, L. A. Gunawan, Review and analysis of current responses to COVID-19 in Indonesia: Period of january to march 2020, Progress in Disaster Science 6, (2020)

[13] J. Martha, Pemanfaatan Diplomasi Publik oleh Indonesia dalam Krisis Covid-19, Jurnal Ilmiah Hubungan Internasional, 121-130 (2020)

[14] S. Chen, J. Yang, W. Yang, C. Wang, T. Bärnighausen, COVID-19 control in China during mass population movements at New Year. The Lancet, 395(10226), 764-766 (2020)

[15] CSSEGISandData, JHU CSSE COVID-19 Dataset, Retrieved from https:/github.com/CSSEGISandData/COVID-19/tree/master/csse_covid_19_data

[16] E. E. Potter, Telecommuting: The future of work, corporate culture, and american society, Journal of Labor Research 24, (1), 73-84 (2003)

[17] N. P. Budhiekusuma, S. P. Hadi, W. W. Winarno, Peluang pemanfaatan telecommuting dalam pemerintahan di Indonesia telecommuting application opportunity in Indonesian government, Jurnal Pekommas, 2(2), 51-160 (2017)

[18] P.A. Grobler, A.J. De Bruyn, High-performance work practices (HPWPs) in determining success of South African companies : fact or fiction?, Journal of Contemporary Management, 15(1), (2018)

[19] M. L. Christin, Flexible Work, Flexible Penalties: The Effect of Gender, Childcare, and Type of Request on the Flexibility Bias, Social Forces 94, (4), 1567-91 (2016)

[20] O. Mungkasa, Bekerja dari Rumah (Working From Home/WFH): Menuju Tatanan Baru Era Pandemi COVID 19, Jurnal Perencanaan Pembangunan: The Indonesian Journal of Development Planning 4.2, 126-150 (2020)

[21] K. P. Panolih, Rumah, Pusat Hidup Normal Baru Saat Pandemi Covid-19, (May 2020), Retrieved from bebas.kompas.id/baca/riset/2020/05/17/rumah-pusat-hidup-normal-baru/

[22] P.A. Bell, J. D. Fisher, R, J. Loomis, Environmental psychology, (Saunders Philadelphia 1974)

[23] Dirjen Pendidikan Nasional, Larangan Kelas Jarak Jauh, (2014), Retrieved from http://www.kopertis3.or.id/html/wp-content/uploads/2014/01/ larangan-kelas-jauh.pdf

[24] A. Masykur, Mengapa kelas jauh harus dilarang?, (2013), Retrieved from http://diktis.kemenag.go.id/NEW/index.php?berita=detil\&jenis=artikel\&jd=167\#. YLJtsKgzaUk

[25] V. B. Pradewo, Nekat Kuliah Kelas Jauh, Waspada Ijazah Bermasalah saat Melamar Kerja, (January 2021), Retrieved from jawapos.com

[26] W. Odom, J. Zimmerman, J. Forlizzi, H. Choi, S. Meier, A. Park, Investigating the presence, form and behavior of virtual possessions in the context of a teen bedroom, 
presented at the the 2012 ACM annual conference, (2012)

[27] A. V. Madzharov, L. G. Block, M. Morrin, The Cool Scent of Power: Effects of Ambient Scent on Consumer Preferences and Choice Behavior, Journal of Marketing, 79(1), 83-96 (2015)

[28] Mendes, A. L. Félix, B. T. L. de Lucena, A. M. G. D. De Araújo, L. P. F. de Melo, L. W. Lopes, M. F. B. de Lima Silva, Voz Do Professor: Sintomas de Desconforto Do Trato Vocal, Intensidade Vocal e Ruído Em Sala de Aula, CoDAS, 28(2), 168-75 (2016) 